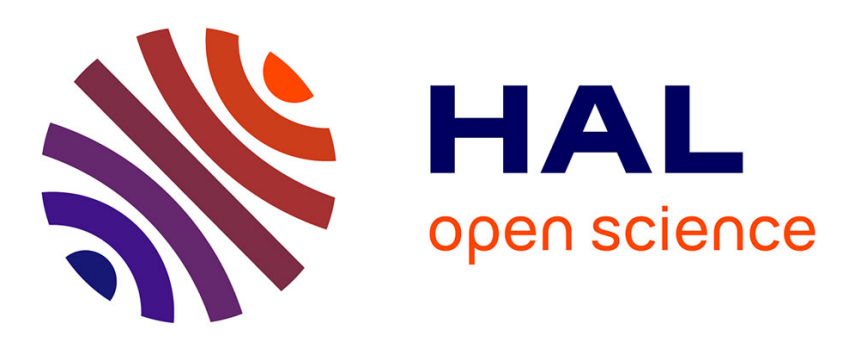

\title{
Factors Influencing Retirement among Older Employees with a Low Occupational Status
}

Sophie Hennekam

\section{To cite this version:}

Sophie Hennekam. Factors Influencing Retirement among Older Employees with a Low Occupational Status. The International Journal of Aging and Society, 2014, 3 (3), pp.45-55. 10.18848/21601909/cgp/v03i03/35118. hal-03232778

\section{HAL Id: hal-03232778 \\ https://hal.science/hal-03232778}

Submitted on 22 May 2021

HAL is a multi-disciplinary open access archive for the deposit and dissemination of scientific research documents, whether they are published or not. The documents may come from teaching and research institutions in France or abroad, or from public or private research centers.
L'archive ouverte pluridisciplinaire HAL, est destinée au dépôt et à la diffusion de documents scientifiques de niveau recherche, publiés ou non, émanant des établissements d'enseignement et de recherche français ou étrangers, des laboratoires publics ou privés. 
Article title : Factors Influencing Retirement among Older Employees with a Low Occupational Status

Authors and Affiliations : Sophie Hennekam, La Rochelle Business School, France

Corresponding author : 


\title{
Title: Factors Influencing Retirement among Older Employees with a Low Occupational Status
}

\author{
Author and affiliation: Sophie Hennekam, La Rochelle Business School, France
}

\begin{abstract}
This study examined the factors that influence the retirement decision of older employees with a low occupational status in the creative industry in the Netherlands. Thirty semi-structured in-depth interviews were conducted by telephone. The sample existed of employees with a low occupational status, aged 50 or above, in the creative industry in the Netherlands. All participants were member of the trade union of this industry. It was found that non-organizational factors play a more important role than organizational factors, such as HRM practices. Three key factors have been identified that might prevent older employees from retiring: a mentality change that is more welcoming towards older employees, a workplace that is highly flexible in the broadest sense of the concept, and regular open communication between the organization and its employees. The findings show that a welcoming mentality towards older employees, greater flexibility, and enhanced communication were found to strongly influence the retirement decision of older employees with a low occupational status.
\end{abstract}

Keywords: Retirement Decision, Low Occupational Status, Netherlands, Older Employees

\section{Introduction}

$\mathrm{T}$ The workforce is aging, a trend that presents some serious challenges to societies worldwide (OECD, 2013). All over the world, people and organizations have started to acknowledge the issues related to an aging population, which has no parallel in human history. Although it is a global phenomenon, individual countries are at different stages of the process and the pace of the demographic change also is highly diverse (United Nations, 2012). Clearly, population aging has profound implications for many facets of human life, including working life.

Older employees in the Netherlands have been encouraged to leave the workforce at early ages during the economic growth, with high youth unemployment rates and generous pension systems. Furthermore, better financial situations and improved healthcare have led to a decrease in retirement age, not only in the Netherlands, but it many European countries (OECD, 2011; Statistics Netherlands, 2014). However, in the light of decreasing fertility rates, increasing life expectancy and the aging of the baby boom generation, governments are now trying to keep older employees in the workforce by increasing the legal retirement age and other financial disincentives (Alley \& Crimmins, 2007; OECD, 2006; 2011; 2013).

Apart from governmental encouragements to stimulate labor participation of older employees, organizations are also putting in place policies and practices to keep older employees longer in the workforce and many studies have been conducted about the factors that influence the retirement decision, like health, finances, marital status or HRM practices (ArmstrongStassen \& Schlosser, 2008; Bidewell, Griffin \& Hesketh, 2006; Boumans, De Jong \& Vanderlinden, 2008; Knoll, 2011; Shacklock \& Brunetto, 2011; Siegrist et al., 2007; Van Dam et al., 2009). However, most studies have focused on older employees with a high occupational status, mainly managers (Herrbach et al., 2009) and older employees with a low occupational status have received only limited attention (Hennekam \& Herrbach, 2013). We argue that older employees with a high and low occupational status differ in the factors that influence their retirement decision. First of all, employees with a low occupational status are likely to be paid less, leading to an increased emphasis on financial factors. Secondly, they are more likely to have

The International Journal of Aging and Society

Volume 3, 2014, www.agingandsociety.com, ISSN 2160-1909

(C) Common Ground, Sophie Hennekam, All Rights Reserved

Permissions: cg-support@commongroundpublishing.com 
physically challenging jobs, resulting in a focus on health-related aspects, like possibilities to go to positions that are physically less strenuous or being exempted from night shifts. Thirdly, older employees with a low occupational status have a double disadvantage and receive possibly less respect and recognition from the organization compared to older employees with a high occupational status. Fourthly, based on their low occupational status, their ideas about how work processes could be improved are less likely to be taken into account, negatively affecting their feelings self-worth and usefulness. This study tries to fill this gap in the literature by looking at the factors that influence the retirement decision of older employees with a low occupational status.

The article will outline the context in which this study took place, will discuss the methodology and will present the findings. The article ends with a discussion and conclusion, outlining the main contributions, implications and limitations.

\section{Context}

This study contributes to the existing body of research by focusing on older employees with a low occupational status in the creative industry in the Netherlands. The creative industry, the aging population in the Netherlands, the particularities of the Dutch pension system and the occupational status of the employees will be discussed in more detail below.

The creative industry is commonly defined as an industry "supplying goods and services that we broadly associate with cultural, artistic, or simply entertainment value" (Caves 2000,1) and that "have their origin in individual creativity, skill and talent" (DCMS, 2001, 5). This industry comprises the commercial and non-commercial industries of architecture and design; film, television, video, radio and publishing; fine arts; music and the performing arts; software and computer gaming; advertising and crafts (DCMS, 2001; UNCTAD, 2008). Examples of occupations are printers, sound technicians, illustrators, actors or graphical designers. The creative industry can be characterized by irregular working hours, periods of unemployment, low job security, physically strenuous tasks and constant changes in terms of technological developments (Braaksma, de Jong \& Stam, 2005; Braams \& Urlings, 2011). These characteristics might influence the retirement decision in the sense that physical hardship, the need to keep up-to-date regarding technology and the irregularity in terms of salary and working hours might push older employees into retirement. Although the industry is growing faster than the national average, a trend that many older employees are leaving the industry can be identified (Braams \& Urlings, 2010).

Secondly, the rate of the demographic aging process in the Netherlands will double in the years to come (Statistics Netherlands, 2011). The acceleration is due to the baby boom generation born after the Second World War who now reaches the age of 65. By the year 2040, the over-65 population will include 4.6 million people versus 2.6 million in 2010 (Statistics Netherlands, 2011). It is important to mention here the particularity of the Dutch pension system that is in strong contrast with the system in most other European countries, except for the United Kingdom. In the Netherlands, employees build up their own pension during their working lives. Labour force participation of older workers has traditionally been low in the Netherlands, compared to other OECD countries (De Vroom \& Bannink, 2007). This is the result of many early exit measures that have been introduced to improve rates of employment amongst younger employees in the 1970s and 1980s (OECD, 2003). These early exit gates are now being closed rapidly (Statistics Netherlands, 2012). A major obstacle is seniority-based pay, which remains dominant in the Netherlands, making older employees relatively unattractive to employers.

A last factor that needs to be discussed is the occupational status of the employees in the present study. The International Standard Classification of Occupations (ISCO) is one of the main international classification tools for organizing jobs. ISCO-08 was used in the present study to classify the occupations of the interviewees in order to compare the average occupational level 
of the interviewees with the average level of participants in previous studies. The ISCO-08 guidelines were used. The ISCO-08 has four ranks. The interviewees in this study had a rank 1 or 2, compared to rank 4 in previous studies.

\section{Factors Influencing the Retirement Decision}

The retirement decision of older employees is a complex and long lasting psychosocial process (Ekerdt, 1998) and many studies have been conducted regarding the factors that influence this decision. It has been argued that financial and health concerns are strongly influence the retirement decision (Knoll, 2011). Poor health tends to co-exist with early retirement (Boumans, De Jong \& Vanderlinden, 2008; Mein et al., 2000) and the development of health interventions tends to co-exist with the intention to delay retirement (Phillipson \& Smith, 2006). Regarding finances, having money tends to co-exist with a preference for later retirement. It has been argued that people with good incomes often also have positions with more responsibilities as well as more challenging and stimulating jobs (Beehr et al., 2000; Herrbach et al., 2009; Shacklock \& Brunetto, 2011) leading them to retire later (Li et al., 2008). However, older employees with a lower occupational status are more likely to have jobs that have little prospects for growth, that are more repetitive in nature, are physically harder to execute and are mentally less challenging (Pillay, Kelly \& Tones, 2006; 2010) leading them to retire earlier (Li, Hurd \& Loughran, 2008). Occupational status is likely to influence how employees experience the world of work and their attitude towards retirement. For employees with a lower occupational status, being in good health and earning a decent income were mentioned as factors that would make them extend their working lives in previous studies (Millward \& Brooke, 2007). Also, it was found that employees with a lower occupational status put the focus on less physically demanding work (Pillay, Kelly \& Tones, 2006), since levels of stress and illness are higher for this group of employees (Buyens et al., 2009).

Previous studies have identified factors that incite employees to retire early and that are likely to be more prevalent among older employees with a low occupational status like being tired of work (Bidewell et al., 2006), low well-being (Mein et al., 2000; Siegrist et al., 2007), low perceived control over the retirement decision (Van Dam et al., 2009) and having a stressful work environment (Elovainio et al., 2005; Mein et al., 2000). The same was found for low wages (Kim \& Feldman, 1998), bad working conditions, excessive workloads, high job demands, poor job control (Elovainio et al., 2005) and negative stereotyping of older employees (Boumans et al., 2008).

This article provides an in-depth, qualitative analysis of the work experiences of employees with a low occupational status in the creative industry in the Netherlands, identifying factors that influence their retirement decision, leading to the research question:

What factors influence the retirement decision of older employees with a low occupational status in the creative industry in the Netherlands?

\section{Methodology}

\section{Sample}

The sample in this study existed of employees that are a member of the trade union FNV-KIEM and work in the creative industry in the Netherlands. The database of this trade union was given

The International Journal of Aging and Society

Volume 3, 2014, www.agingandsociety.com, ISSN 2160-1909

(C) Common Ground, Sophie Hennekam, All Rights Reserved

Permissions: cg-support@commongroundpublishing.com 
to the researcher who then contacted directly the interviewees. FNV-KIEM has a total of 34286 members of which $73,5 \%$ is men. Their age ranges from 14 to 100 years, with an average age of 55. The interviewees in the study were between 50 and 59 years old, with an average of $55.80 \%$ of the interviewees was male and $20 \%$ was female, based on the relatively small sample in general and especially the small number of women interviewees, comparison between men and women was not feasible. Since a list with only surnames, telephone numbers, function and date of birth of members of the trade union was provided, the researcher was unable to use purposive sampling, as no other characteristics were available to the researcher. The only two selectioncriteria were age and occupational status. In line with the definition of the OECD (2006), older employees are defined as employees aged 50 or older, which was the threshold adopted in this study. In order to determine the occupational status of the employees under study the International Standard Classification of Occupations (ISCO) 2008 has been used. 63\% of the interviewees (19) had a rank 2 occupation and 11 interviewees (37\%) had a rank 1 occupation.

\section{Procedures}

A total of 89 telephone calls were made. 16 individuals were absent, 4 no longer worked in the sector and 9 did not wish to participate. This gives a response rate of $67.4 \%$. Interviewees were phoned randomly from the database. Thirty interviewees were interviewed. The number of interviews to be conducted was not determined beforehand. However, after 30 interviews there was a point of saturation where little new information was obtained and where similar patterns came back, so it was decided to stop after having conducted 30 interviews.

Semi-structured in-depth interviews were chosen since they provide an opportunity for detailed investigation of personal views and experiences of each interviewee. An interview guide was used but additional questions not present in the interview guide were asked as the researcher picked up on things said by the interviewee. The researcher had a clear focus of investigation, so semi-structured interviews were preferred over unstructured interviews so that the more specific issues could be addressed. Techniques to achieve depth were careful listening, probing and summarizing in other words what has been said to verify if the interpretation of the researcher is correct or needs adjustment, emphasizing there were no right or wrong answers, expressing interest and attention and giving the interviewee enough time to reply (Silverman, 2011). The interpretation of the researcher of what had been said was checked with the interviewee immediately to make sure the researcher had correctly understood the interviewee. Leading questions were avoided and questions were formulated in such a way they were understandable for the population under study (Mason, 2002). The questions were open-ended.

The semi-structured interviews were conducted by telephone. The interviews lasted for about one to one-and-a-half hour. A disadvantage is that people can lose patience. Another limitation created by telephone interviews concerns the lack of body language and facial expressions which play important roles in human communication. Despite these limitations, telephone interviews also present some advantages compared to face-to-face interviews. Telephone interviews are cheaper and quicker to administer, it provides more reliable evidence and the risk of interviewer effects on responses on the interviewee might be less pronounced in telephone interviews (Silverman, 2011).

\section{Analysis}

All interviews were tape recorded, fully transcribed and analyzed by hand. Content analysis was used to analyze the data (Stemler, 2001). Content analysis has been defined as a systematic, replicable technique for compressing many words of text into fewer content categories based on explicit rules of coding (Weber, 1990) and entails inspection of the data for recurrent instances of some kind (Wilkinson, 2011). The rich and detailed information obtained during the in-depth interviews are summarized and explained without losing sight of the wealth of information by the 
use of supporting quotations. Frequency counting has been used, assuming that the words that are mentioned most often reflect the greatest concerns. We checked for synonyms not to underestimate the importance of a concept (Weber, 1990) and we are aware that words have multiple meanings. Also, we are aware of the fact that each word might not represent a category equally well and that not all issues are equally difficult to raise (Weber, 1990).

Two coders were used to reduce error and bias in coding the transcripts (Mays \& Pope, 2000) and the inter-coder reliability has been established. Cohen's kappa (Cohen, 1960) was used in order to avoid chance agreement. Low initial inter-coder reliabilities of .48-.57 were found and two to six rounds of discussions between the coders, modification of the codebook, coding and calculating the inter-coder reliability were necessary to obtain reliabilities of .81 to .94 . An intercoder reliability of .80 was used as a cut-off point (Miles \& Huberman, 1994)

\section{Results}

This study examined which factors influence the retirement decision of older employees with a low occupational status in the creative industry in the Netherlands.

Three main factors have been identified: the negative attitude towards older employees, flexibility and communication. These three factors will be discussed in more detail below.

The first factor is 'negative attitudes towards older employees'. It seems that older employees with a low occupational status have a double disadvantage: they belong to two devalued social groups namely older employees and low occupational status employees. Twothird of the interviewees in this study reported age discrimination, negative attitudes and preconceived ideas about those two social groups they belonged to. They explained that these negative attitudes push them into retirement, since they simply can not continue to work in such a hostile environment. The following excerpts reflect the feeling of more than two-thirds of the interviewees about this issue:

Male, 57 years: They hinted that they thought I wouldn't be as alert, that I couldn't follow the current trends, that type of stuff. It makes you a bit depressed, powerless also, because you can't change your age. It's unfair, but well, for the price of one 40-year old they can hire three people in their twenties. Instead of looking at their experience... that comes only on the second or third place. Finances are still their main consideration.

Almost a quarter of the interviewees explained that they experience a theory-reality paradox in that the government is trying to stimulate older employees to work longer, but that this is not happening in practice because of the existing negative stereotypes and discriminatory practices. It might be that this is even stronger in the creative industry in the Netherlands since the average age of the people working in this industry is relatively young, leading to being considered 'old' at a younger age compared to other industries. It was found that from the age of 40-45 onwards employees became subject of negative stereotyping and discrimination.

Female, 50 years: They (the government) are always talking about working longer and longer, but it's kind of double. One the one hand they say that you have to stay longer in the workforce, but when you lose your job at 45 you won't find a new job because you're too old you see. They don't say it, but that's how it is in practice.

The International Journal of Aging and Society

Volume 3, 2014, www.agingandsociety.com, ISSN 2160-1909

(C) Common Ground, Sophie Hennekam, All Rights Reserved

Permissions: cg-support@commongroundpublishing.com 
The second factor was flexibility, which was mentioned by 24 interviewees. Flexibility seems to become increasingly important as one gets older. This concept of flexibility is very broad and was interpreted in several ways. Some interviewees wanted flexibility in terms of flexible work options like working fewer hours, or having the possibility to work from home, others talked about flexibility as being able to do different tasks, while others mentioned that they want less meetings and get more freedom to execute their tasks. It seemed that flexibility for many interviewees also referred to being able to continue work while enjoying other aspects of life, that they wanted the organization to be flexible in order to keep on working while at the same time having other commitments. The following excerpt shows the importance of flexibility:

Female, 51 years: I'd like to work longer, even beyond the legal retirement age, but not the way I'm working now. I want to be able to juggle the different activities I'm committed to. Work, yes, but also my personal life, there has to be a balance. If the organization would offer me this balance by providing a part time job with flexible hours and just a nice simple job that I enjoy doing, I'd definitely consider to work longer.

Male, 52 years: I'm a printer and I'm working night shifts, I find this increasingly difficult. My body is getting older, physically it's quite hard. I wish I could retire earlier, I don't see myself doing this for another 10-15 years. Flexibility in terms of working hours, either moving an administrative position that is physically easier or having only day shifts, that's what I want.

The last factor identified in the data was communication. Communication was a big point of dissatisfaction among the interviewees as signaled by half of all older workers in this study. They stated organizations often do not listen to them when interviewees have an idea to improve things and they mentioned that organizations communicate very little about how things are going. They explain that they would not mind extending their working lives if they would be working at an organization that listens to what they have to say. More communication between employees and employers about the wishes of employees and how they can take these into account were expressed as something many interviewees would appreciate. This excerpt is characteristic for the feelings of many interviewees about this issue.

Male, 51 years: I don't like my job at the moment. I'm far too young to stop working of course, but I'd like to stop at the age of 57. Well, I'd like to work longer, but in order to function properly you have to communicate. It's important that employers and employees get round the table and talk about what you want. But they don't and that's why people want to retire so early.

\section{Discussion and Conclusion}

This study examined the factors that influence the retirement decision of the older employees with a low occupational status in the creative industry in the Netherlands.

It was found that the negative mentality towards older employees, flexibility and communication influenced most strongly their retirement decision. It seems that the negative attitudes towards older employees with a low occupational status push those employees into retirement, not only because they have difficulty finding a job when they become unemployed, but also by creating an unfriendly and unwelcoming environment for those employees making them feel 'too much' and therefore leading to early retirement. The fact that the negative attitudes towards older employees strongly influenced the retirement decision of this group of employees 
might be the result of the industry under study. The creative industry is known for its high levels of age discrimination, the physically challenging jobs and its preference for younger employees (Braaksma, de Jong \& Stam, 2005; Braams \& Urlings, 2010).

Furthermore, when it is not possible to balance work with other commitments, and when flexible working hours and jobs with fewer responsibilities are unavailable, this led the interviewees in this study to opt for early retirement. It is likely that women have other commitments like caring responsibilities to a greater extent than men, resulting in an increased need for flexibility. Previous studies have found that women wish to retire earlier than men and it has been argued that women retire indeed earlier because of their jobs are incompatible with other commitments (OECD, 2013). Previous studies have shown that flexible work options are a priority for older employees and the key to their continued participation in an organization (Piotr, 2009; Warren \& Kelloway, 2010; Winkelmann-Gleed, 2012). Although a majority of older workers plan to extend their work life, many of them wish to move away from the standard nineto-five, five-day work week (Pitt-Catsouphes \& Smyer, 2006), stating that they desire flexible work arrangements and reduced hours (Warren \& Kelloway, 2010; Winkelmann-Gleed, 2012). Shacklock and Brunetto (2011) also stressed the importance of working to the individual and the flexibility of working arrangements as well as Winkelmann-Gleed (2012) who showed the importance to balance financial security in later life with the positive elements of work and the desire to match work with other commitments. Another issue related to the concept of flexibility is the notion of choice. The older employees in the present study explained that the simple fact that the retirement decision is a personal choice or a necessity influences this decision, so that a feeling of choice delays retirement. As such, one can argue that by increasing older employees' choices of retirement options, an organization might be able to make them extend their working lives.

Finally, the lack of communication between the organization and the employees both in terms of having something to say and being listened to makes interviewees retire earlier than if there would be a free exchange of ideas and regular communication. Open and regular communication with employees may affirm their perception of the organization's readiness to provide any possible assistance if needed. As such, it is a form of organizational support that has been found to be negatively related to a preference for early retirement in previous studies (Rhoades \& Eisenberger, 2002).

These findings have some practical implications. In the light of the aging population, organizations will have to retain older employees and make them work until or beyond the legal retirement age. More research about which factors influence the retirement decision of older employees is therefore needed. This study adds to the existing body of knowledge by looking at older employees with a low occupational status. Although many organizations assume that the provision of HRM practices like getting special assignments or promotions will make employees work longer, this study found that the provision of HRM practices was not considered important in this decision. Based on the social exchange theory, organizations often provide HRM practices like training or special assignments to try to retain older employees. Indeed, it can be argued that HRM practices are perceived as 'signals' that the organization wants to extend their exchange relationship with them and are interpreted as such by individual employees (Boon, Den Hartog, Boselie \& Paauwe, 2011). However, not only do older employees with a low occupational status have less access to certain HRM practices, the provision of such practices is likely to lead to positive organizational outcomes only if they are relevant to them. Clearly, for older employees with a low occupational status, the focus is on being able to continue working in a pleasant way in an organization where they feel valued and supported and with a job that fits them both

The International Journal of Aging and Society

Volume 3, 2014, www.agingandsociety.com, ISSN 2160-1909

(C) Common Ground, Sophie Hennekam, All Rights Reserved

Permissions: cg-support@commongroundpublishing.com 
physically and psychologically. For this group of employees, it is important for organizations to acknowledge and fight the negative stereotypes, provide older employees with the possibility to balance work with other commitments and communicate with them about their individual needs and wishes in order to avoid early retirement.

Nowadays, more and more organizations are providing age-awareness policies. However, it is unclear if such policies actually address the concerns of older employees with a low occupational status, or if they are mainly focusing on older employees with a higher occupational status like older managers. The findings seem to indicate that especially double disadvantaged groups in organizations have some deep-rooted and persistent problems that hinder their continuous employment. Although "superficial" policies like age-awareness policies are put in place, the underlying problems like the negative stereotypes and discrimination are not tackled. This study shows that those deeper aspects like the negative mentality, the lack of communication and the inflexible attitude of organizations towards older employees with a low occupational status push those individuals into retirement. Organizations should make sure they are dealing with the underlying problems when trying to keep different groups of older employees longer in the workforce. These recommendations are true for the creative industry in the Netherlands, but future studies should show if the findings also apply in other industries and in other countries. The findings might have some specific implications for women. Since women are a minority group, having to deal with several stigmatized social identities is likely to push them into early retirement. The creation of a more welcoming attitude towards older employees with a low occupational status is therefore even more important for employees, like women, who belong to other minority groups in the workplace.

This study has several limitations and implications for future research. First, the sample existed of older employees with a low occupational status in the creative industry in Netherlands and member of the trade union FNV-KIEM. As a consequence, findings cannot be generalized to older employees working in other sectors or in a different national culture, especially since the particularities of the industry under study are likely to influence the findings obtained. As a consequence, more research is necessary to see whether these results hold true for other samples. Another limitation relates the qualitative nature of this study. Although this type of research provides in-depth insights about the retirement decision of this group of employees it does not allow for statistical testing and only provides clues for further research. Quantitative research is necessary to test this statistically. A related limitation is the role of the researcher. According to Heron (1996), a researcher shows his or her values at all stages in the research process. Since the researcher is the primary "instrument" of data collection and analysis in qualitative studies, reflexivity is deemed essential (Russell \& Kelly, 2002). Despite the above-mentioned limitations, this provides some insights in the retirement decision of older workers and can be used as a platform for future studies. 


\section{REFERENCES}

Alley, D., \& Crimmins, E. 200), “The demography of aging and work", in Shultz, K.S. and

Adams, G.A. (Eds), Aging and Work in the 21st Century, Lawrence Erlbaum Associates, Mahwah, NJ, 7-24.

Armstrong-Stassen, M., \& Schlosser, F. 2008. "Benefits of a supportive development climate for older workers". Journal of Managerial Psychology 23(4): 419-437.

Beehr, T. A., Norma, S.G., Nielson, L., \& Farmer, S. J. 2000. "Work and Nonwork Predictors of Employees' Retirement Ages". Journal of Vocational Behavior 57(2): 206-225.

Bidewell, J., Griffin, B., \& Hesketh, B. 2006. "Timing of Retirement: Including a Delay Discounting Perspective in Retirement Models". Journal of Vocational Behavior 68(2): 368-387.

Boon, C., Den Hartog, D., Boselie, P., \& Paauwe, J. 2011. "The relationship between perceptions of HR practices and employee outcomes: examining the role of person-organisation and person-job fit". The International Journal of Human Resource Management 22(1): 138162.

Boumans, N. P. G., De Jong, A. H. J., \& Vanderlinden, L. 2008. "Determinants of early retirement intentions among Belgian nurses". Journal of Advanced Nursing 63(1): 6474.

Braaksma, R. M., de Jong, J. P. J., \& Stam, E. 2005. Creatieve bedrijvigheid in Nederland, EIM. Braams, N., \& Urlings, N. 2010. Creatieve industrie in Nederland, Creatieve bedrijven, CBS.

Braams, N., \& Urlings, N. 2011. Creatieve industrie in Nederland, Creatieve beroepen, CBS.

Bryman, A., \& Bell, E. 2008. Business Research Methods. Oxford: Oxford University Press.

Buyens, D., Van Dijk, H., Dewilde, T., \& De Vos, A. 2009. "The aging workforce: perceptions of career ending”. Journal of Managerial Psychology 24(2): 102-117.

Caves, R. E. 2000. Creative Industries. Harvard University Press, Cambridge.

Cohen, J. 1960. "A coefficient of agreement for nominal scales". Educational and Psychosocial Measurement, 20(1): 37-46.

Department for Culture, Media and Sport (DCMS) 2001, Creative Industries Mapping Document, DCMS, London.

De Vroom, B., \& Bannink, D. 2007. Employment and labour market policies for an ageing workforce and initiatives at the workplace. National overview report: The Netherlands. European Foundation for the Improvement of Living and Working Conditions, 1-9.

Ekerdt, D.J. 1998. Workplace Norms for the Timing of Retirement. Springer Publishing, New York.

Elovainio, M., Forma, P., Kivima, M., Timo, K., Sutinen, R., \& Laine, M. 2005. "Job demands and job control as correlates of early retirement thoughts in Finnish social and health care employees". Work \& Stress 19(1): 84-92.

Gadamer, H.-G. 1975. Truth and Method. London: Sheed and Ward.

Hennekam, S., \& Herrbach, O. 2013. "HRM practices and low occupational status older workers". Employee Relations 35(3): 339-355.

Heron, J. 1996. Co-operative Inquiry: research into the human condition. London: Sage.

Herrbach, O., Mignonac, K., Vandenberghe, C., \& Negrini, A. 2009. "Perceived human resource management practices, organizational commitment and voluntary early retirement among late-career managers". Human Resource Management 48(6): 895-915.

Kim, S., \& Feldman, D. C. 1998. "Healthy, wealthy, or wise: Predicting actual acceptances of early retirement incentives at three points in time". Personnel Psychology 37: 71-84.

The International Journal of Aging and Society

Volume 3, 2014, www.agingandsociety.com, ISSN 2160-1909

(C) Common Ground, Sophie Hennekam, All Rights Reserved

Permissions: cg-support@commongroundpublishing.com 
Knoll, M. A. Z. 2011. "Behavioral and psychological aspects of the retirement decision". Social Security Bulletin 71(4): 15-32.

Li, X., Hurd, M., \& Loughran, D. S. 2008. The Characteristics of Social Security Beneficiaries Who Claim Benefits at the Early Entitlement Age. AARP Public Policy Institute Research Report No. 2008-19. Washington, DC: AARP.

Mason, J. 2002. Qualitative Researching. London: Sage.

Mays, N., \& Pope, C. 2000. "Assessing quality in qualitative research". British Medical Journal 320(1): 50-2.

Mein, G., Martikainen, P., Stansfeld, S.A., Brunner, E.J., Fuhrer, R., \& Marmot, M.G. 2000. "Predictors of early retirement in British civil servants". Age and Ageing 29(6): 529-36.

Miles, M. B., \& Huberman, A. M. 1994. Qualitative data analysis. Thousand Oaks, CA: Sage.

Millward, C., \& Brooke, L. 2007. Should we work longer? Public expectations about older workers and retirement, in Denemark, D., Meagher, G., Wilson, S., Western, M. and Phillips, T. (Eds), Australian Social Attitudes 2: Citizenship, Work and Aspirations, UNSW Press, Sydney.

OECD 2003. Retirement behaviour in OECD countries: Impact of old-age pension schemes and other social transfer programmes, Paris: OECD.

OECD 2006. Live longer, work longer. Paris: OECD.

OECD 2011. Trends in Retirement and in Working at Older Ages, in Pensions at a Glance 2011: Retirement-income Systems in OECD and G20 Countries, Paris: OECD.

OECD 2013, Pensions at a Glance 2013: Retirement-Income Systems in OECD and G20 countries. Paris: OECD.

Phillipson, C., \& Smith, A. 2006. Extending Working Life: A Review of the Research Literature. Department of Work and Pensions, London, 299.

Pillay, H., Kelly, K., \& Tones, M. 2006. "Career aspirations of older workers: an Australian Study”. International Journal of Training \& Development 10(4): 298-305.

Pillay, H., Kelly, K., \& Tones, M. 2010. "Transitional employment aspirations for bridging retirement: Implications for training and development". Journal of European Industrial Training 34(1): 70-86.

Piotr, Z. 2009. "Human resources practices and work-related attitudes in Polish public administration". Eastern European Economics 47(5): 42-60.

Pitt-Catsouphes, M. \& Smyer, M. 2006. One size doesn't fit all. Workplace Flexibility. Issue Brief 05. Chestnut Hill, MA: The Center on Aging \& Work/Workplace Flexibility.

Rhoades, L., \& Eisenberger, R. 200). "Perceived organizational support: A review of the literature". Journal of Applied Psychology 87: 698-714.

Russell, G. M., \& Kelly, N. H. 2002. Research as interacting dialogic processes: Implications for reflexivity. Forum: Qualitative Social Research, 3(3). Retrieved June 15, 2013, from http://www.qualitative-research.net/fqstexte/3-02/3-02russellkelly-e.htm

Shacklock, K., \& Brunetto, Y. 2011. "A model of older workers' intentions to continue working". Personnel Review 40(2): 252-274.

Siegrist, J., Wahrendorf, M., von dem Knesebeck, O., Jürges, H, \& Börsch-Supan, A. 2007. "Quality of work, well-being, and intended early retirement of older employees. Baseline results from the SHARE study". European Journal of Public Health 17(1): 62 68.

Silverman, D. 2011. Interpreting qualitative data. London: Sage Publications.

Statistics Netherlands 2011. Rate demographic ageing process doubles.

Statistics Netherlands 2012. Employed labour force is ageing.

Statistics Netherlands 2014. Average retirement age employees further up to nearly 64 years.

Stemler, S. 2001. "An overview of content analysis", Practical Assessment, Research \& Evaluation, 7(17): 1-5.

UNCTAD 2008. Creative Economy Report 2008, UNDP, New York. 
United Nations 2012, World Population Ageing: 1950-2050.

Van Dam, K., Van der Vorst, J. D. M., \& Van der Heijden, B. I. J. M. 2009. 'Employees' intentions to retire early". Journal of Career Development 35(3): 65-289.

Warren, A., \& Kelloway, E. K. 2010. "Retirement timing in the context of the decision to abolish mandatory retirement". International Journal of Manpower Planning 31: 281-305.

Weber, R. P. 1990. Basic Content Analysis. Newbury Park, CA.

Wilkinson, R. 2011. "Changing interactional behaviour: Using conversation analysis in intervention programmes for aphasic conversation", In: Applied Conversation Analysis: Changing Institutional Practices, 32-53. Basingstoke: Palgrave Macmillan.

Winkelmann-Gleed, A. 2012. "Retirement or committed to work?: Conceptualising prolonged labour market participation through organisational commitment". Employee Relations 43(1): 80-90.

\section{ABOUT THE AUTHORS}

Dr. Sophie Hennekam: Teacher-Researcher in Human Resource Management at La Rochelle School of Business School, La Rochelle, France. 